\title{
Importance of ciliates as prey of the euphausiid Euphausia pacifica in the NW North Pacific
}

\author{
Yoshizumi Nakagawa ${ }^{1,3, *}$, Takashi Ota ${ }^{1}$, Yoshinari Endo $^{1}$, Kenji Taki $^{2}$, Hiroya Sugisaki $^{2}$ \\ ${ }^{1}$ Graduate School of Agricultural Science, Tohoku University, Sendai 981-8555, Japan \\ ${ }^{2}$ Tohoku National Fisheries Research Institute, Shiogama 985-0001, Japan \\ ${ }^{3}$ Present address: Fisheries Laboratory of Kinki University, 1-5, Shirahama, Nishimuro, Wakayama 649-2200, Japan
}

\begin{abstract}
We investigated the feeding of Euphausia pacifica on ciliates, especially naked ciliates, in laboratory and field experiments in which cultured Strombidium conicum, or natural food assemblages, or both were given, and estimated the importance of ciliates as prey. E. pacifica ingested cultured S. conicum at rates of 0.04 to $0.07 \mu \mathrm{g} \mathrm{C} \mathrm{krill}^{-1} \mathrm{~h}^{-1}$ at low ciliate concentration and 1.01 to $3.24 \mu \mathrm{g} \mathrm{C}$ krill $^{-1} \mathrm{~h}^{-1}$ at high ciliate concentration, when $S$. conicum was given as the sole prey. The daily ration on naked ciliates ranged from 0.02 to $1.8 \%$ of body carbon when natural food assemblages enriched with $S$. conicum were given, and from 0.05 to $2.3 \%$ of body carbon when $S$. conicum was given as the sole prey. Our results provide indirect evidence that E. pacifica ingests naked ciliates and plays a role in linking microbial food webs to the classical grazing food chains.
\end{abstract}

KEY WORDS: Euphausia pacifica $\cdot$ Feeding $\cdot$ Naked ciliates $\cdot$ Strombidium conicum $\cdot$ Food removal Resale or republication not permitted without written consent of the publisher

\section{INTRODUCTION}

Planktonic protozoans function as important trophic intermediaries in pelagic food webs by repacking small bacterial and algal cells into food items large enough to be consumed by mesozooplankton (Gifford 1993, Båmstedt et al. 2000). The C:N ratio in heterotrophic marine protozoans is lower than the values usually reported for phytoplankton and mixotrophic protozoans, making protozoans a richer source of amino acids and protein than phytoplankton and detritus (Stoecker \& Capuzzo 1990). In particular, planktonic ciliates have been recognized as abundant, ubiquitous and therefore important components of marine microbial food webs (Pierce \& Turner 1992). The carbon:biomass ratio of ciliates to net-zooplankton could amount to as much as $36 \%$ in the sea off NE Japan (Ito 2002). Planktonic ciliates have been considered potentially important prey for mesozooplankton owing to their available size and vertical distribution (Stoecker \& Capuzzo 1990). Several studies have documented the consumption of protozoans, including ciliates, by copepods, and have demonstrated the role of copepods in linking the microbial food webs to the classical grazing food chains (reviewed by Stoecker \& Capuzzo 1990, Gifford 1993).

Perissinotto et al. (1997) reported that athecate ciliates were very abundant in the gut contents of Euphausia superba. However, it is not clear whether E. superba ingests planktonic athecate ciliates, since symbiotic ciliates reproduce in the gut (Kawaguchi \& Toda 1997). In rearing experiments, calanoid copepods and protozoans proved to be the major prey items of E. superba when natural seawater was given as food (Atkinson \& Snÿder 1997). Athecate protozoans, including naked ciliates, however, are not identifiable in the stomach contents of euphausiids, because they do not have any hard body parts (Stoecker \& Capuzzo 1990, Nakagawa et al. 2001, 2002).

On the basis of gut-content analysis, several studies have suggested that Euphausia pacifica is an omnivore (Ponomareva 1963, Mauchline \& Fisher 1969, Endo 1981). Nakagawa et al. (2002) suggested that naked ciliates could be a major prey item of E. pacifica after copepods, assuming that naked ciliates and tintinnids were ingested equally in proportion to their biomass in 
the ambient water. However, this hypothesis lacks the direct evidence that E. pacifica ingests naked ciliates. The present study aimed to investigate the ingestion rates of E. pacifica on ciliates, especially naked ciliates, in the field and laboratory to estimate the importance of naked ciliates as prey.

\section{MATERIALS AND METHODS}

All the experiments used the food removal method (Båmstedt et al. 2000) under the following 3 food conditions.

Strombidium conicum as sole food source. S. conicum was used as the sole food source to examine whether Euphausia pacifica ingests this naked ciliate and, if so, what the ingestion rates are. Experiments were carried out from 20 to 23 March 2001 (Table 1) at the Education and Research Center of Marine Bioresources (ERCMB), Tohoku University. Adult E. pacifica were collected from a surface swarm in a dip net with a $5 \mathrm{~mm}$ mesh at 13:00 h on 20 March 2001 at the port of Tanoshiri $\left(38^{\circ} 27^{\prime} 25^{\prime \prime} \mathrm{N}, 141^{\circ} 31^{\prime} 12^{\prime \prime} \mathrm{E}\right)$; sea depth was about $2 \mathrm{~m}$ and surface water temperature was $5.8^{\circ} \mathrm{C}$. Live individuals of E. pacifica were transferred to a 201 polycarbonate bottle filled with the surface seawater after rinsing in filtered seawater. The temperature was maintained at 8.9 to $10.3^{\circ} \mathrm{C}$ in a water bath, and $50 \%$ of the seawater in the bottle was changed daily; the molts and dead individuals were removed from the bottle at the same time.

Strombidium conicum had been cultured, with the haptophyte Isochrysis sp. as food, at $20^{\circ} \mathrm{C}$ for $12 \mathrm{~h}$ in the dark, and were in active growth phase. Their average carbon content was $12.2 \pm 2.3 \mathrm{ng} \mathrm{C}$ cell $^{-1}$. They measured $83.6 \pm 4.2 \mu \mathrm{m}$ long $\times 47.5 \pm 3.6 \mu \mathrm{m}$ wide (mean $\pm \mathrm{SD})$. Cultured $S$. conicum was given at either high (5000 cells $\mathrm{l}^{-1}$ ) or low (300 cells $\mathrm{l}^{-1}$ ) concentration at night on 22 March and during the day on 23 March. We prepared two 11 bottles containing 1 euphausiid each for both concentrations of S. conicum, and another 2 bottles without a euphausiid for both concentrations as controls. Incubation water with a high concentration of $S$. conicum was prepared by mixing $280 \mathrm{ml}$ of $S$. conicum culture with $820 \mathrm{ml}$ of seawater filtered through a Whatman GF/F filter, to give a final concentration of 5000 cells $\mathrm{l}^{-1}$. Water with a low concentration was prepared by mixing $20 \mathrm{ml}$ of $S$. conicum culture with $1230 \mathrm{ml}$ of GF/F-filtered seawater, to give a final concentration of 300 cells $\mathrm{l}^{-1}$. These concentrations of ciliates were within the reported range of the abundance of total naked ciliates in the northwestern North Pacific (Ito \& Taniguchi 2001, Ito 2002). Diatoms contaminated the incubation water (probably brought in with Euphausia pacifica) at concentrations ranging from 0 to 1630 cells $\mathrm{l}^{-1}$ at the start of the experiment.

Table 1. Experimental conditions and initial biomass of phytoplankton, naked ciliates and tintinnids in each experiment. Surface seawater was filtered through $200 \mu \mathrm{m}$ mesh, except where otherwise indicated

\begin{tabular}{|c|c|c|c|c|c|}
\hline Food source & $\begin{array}{l}\text { Mean body } \\
\text { carbon } \\
(\mathrm{mg})\end{array}$ & $\begin{array}{c}\text { Experimental } \\
\text { temperature } \\
\left({ }^{\circ} \mathrm{C}\right)\end{array}$ & $\begin{array}{l}\text { Phytoplankton } \\
\left(\mu{\left.\mathrm{C} \mathrm{l}^{-1}\right)}\right.\end{array}$ & $\begin{array}{c}\text { Initial biomass } \\
\text { Naked ciliates } \\
\left(\mu \mathrm{C} \mathrm{C} \mathrm{l}^{-1}\right)\end{array}$ & $\begin{array}{c}\text { Tintinnids } \\
\left(\mu \mathrm{C}^{-1}\right)\end{array}$ \\
\hline \multicolumn{6}{|c|}{ Strombidium conicum } \\
\hline 22 Mar 01 & 3.4 & $10.2-10.3$ & 20.87 & & \\
\hline 22 Mar 01 & 1.6 & $10.2-10.3$ & 1.37 & & \\
\hline 23 Mar 01 & 2.6 & $9.8-10.2$ & 24.34 & & \\
\hline 23 Mar 01 & 1.8 & $9.8-10.2$ & 2.71 & & \\
\hline \multicolumn{6}{|c|}{ Natural seawater } \\
\hline 14 Sep 00 & 1.6 & $11.9-12.1$ & 40.62 & 0.56 & 0.04 \\
\hline 3 Oct 00 & 1.8 & $5.2-7.1$ & 31.31 & 1.26 & 0.20 \\
\hline 5 Oct 00 & 2.9 & $12.2-12.9$ & 41.58 & 1.04 & 0.04 \\
\hline 6 Oct 00 & 3.0 & $12.6-12.7$ & 5.64 & 0.67 & 0.07 \\
\hline 7 Oct 00 & 3.2 & $11.8-12.1$ & 10.34 & 1.02 & 0 \\
\hline 22 Mar 01 & 2.6 & $10.2-10.3$ & 28.50 & 16.22 & 0.31 \\
\hline 23 Mar 01 & 2.5 & $9.8-10.0$ & 53.62 & 23.45 & 0.12 \\
\hline 11 Apr 01 & 4.2 & $8.7-9.6$ & 151.05 & 8.43 & 1.85 \\
\hline 14 Apr 01 & 3.6 & $8.9-10.2$ & 42.07 & 2.91 & 0.66 \\
\hline $14 \mathrm{Apr} 01^{\mathrm{a}}$ & 3.8 & $8.9-10.2$ & 74.85 & 2.36 & 0.06 \\
\hline 15 Apr $01^{\mathrm{a}}$ & 4.9 & $11.1-11.3$ & 35.23 & 6.93 & 0 \\
\hline \multicolumn{6}{|c|}{ Natural seawater $+S$. conicum } \\
\hline 20 Mar 01 & 3.4 & $9.4-9.8$ & 79.56 & 6.01 & 0.30 \\
\hline 21 Mar 01 & 1.6 & $9.4-9.8$ & 61.98 & 13.60 & 0.11 \\
\hline 21 Mar 01 & 2.6 & $9.4-9.7$ & 122.72 & 20.32 & 0.36 \\
\hline 22 Mar 01 & 2.8 & $8.9-9.4$ & 91.10 & 5.52 & 0 \\
\hline
\end{tabular}


The incubation water was left for 2.8 to $3.5 \mathrm{~h}$ after introduction of the $S$. conicum cultures into the bottles to acclimatize the $S$. conicum (Gifford 1993, Båmstedt et al. 2000). All experiments and acclimatization were carried out in the dark at 9.8 to $10.9^{\circ} \mathrm{C}$ by covering the experimental container with a sheet of black rubber. Experiments lasted only $6 \mathrm{~h}$ in order to conform to 2 other experiments in which natural food assemblages were given.

At the start and end of the experiment, a 100 to $250 \mathrm{ml}$ sample was collected with a siphon from each bottle after mixing, and preserved in $1 \%$ Lugol's solution for enumeration of ciliates. Each Euphausia pacifica was then rinsed with distilled water to remove attached materials, and preserved in 5\% Bouin's solution.

Natural food assemblages. Experiments in which natural food assemblages were given as food source were carried out during 3 cruises of the RV 'WakatakaMaru', RV 'Tankai-Maru' and RV 'Tansei-Maru', and at ERCMB from 14 September 2000 to 15 April 2001 (Table 1) in the coastal waters off northeastern Japan. Adult Euphausia pacifica were collected at night by vertical tow from $100 \mathrm{~m}$ depth, in a conical net with a mouth diameter of $56 \mathrm{~cm}$, a mesh aperture of $200 \mu \mathrm{m}$ and a $11 \mathrm{cod}$ end. At ERCMB, after rinsing in filtered seawater, live animals were transferred to 201 polycarbonate bottles filled with surface seawater and were maintained at 8.7 to $12.9^{\circ} \mathrm{C}$ in a water bath (except for the experiment on 3 October: 5.2 to $7.1^{\circ} \mathrm{C}$ ), for 1.4 to $3.0 \mathrm{~h}$ to acclimatize them before experiments. The incubation water, with food, was collected from the sea surface in a plastic bucket on board the research vessels, while the water at ERCMB was collected from the innermost part of Onagawa Bay $\left(38^{\circ} 25^{\prime} \mathrm{N}, 141^{\circ} 30^{\prime} \mathrm{E}\right)$, and was transferred gently to $20 \mathrm{l}$ polycarbonate bottles through a silicon tube with a 40 or $200 \mu \mathrm{m}$ mesh attached to eliminate copepods and larger zooplankton, which can ingest ciliates (Båmstedt et al. 2000). These bottles were left for 1.4 to $3.0 \mathrm{~h}$ to acclimatize the natural food assemblage. Experiments were done in 201 bottles with 3 to 5 live euphausiids or without euphausiids as a control. Experiments lasted only $6 \mathrm{~h}$ in order to reduce grazing by zooplankton other than euphausiids in the control bottles (Gifford 1993).

At the start and end of the experiment, after mixing, two 250 to $500 \mathrm{ml}$ samples were collected with a siphon from each bottle for chlorophyll a analysis and for enumeration of ciliates. The sample for enumeration of ciliates was preserved in $1 \%$ Lugol's solution. Subsamples of $100 \mathrm{ml}$ for chlorophyll a analysis were sizefractionated through $10 \mu \mathrm{m}$ nylon mesh and a GF/F filter. No size-fractionation was done in the experiments in September and October 2000: $100 \mathrm{ml}$ subsamples were just filtered though GF/F filters. After $6 \mathrm{~h}$ incubation, Euphausia pacifica was checked for activity. Indi- viduals were rinsed with distilled water to remove attached materials, transferred to a pre-combusted $\left(450^{\circ} \mathrm{C}, 6 \mathrm{~h}\right)$ and pre-weighed $\mathrm{GF} / \mathrm{C}$ filter, and frozen at $-80^{\circ} \mathrm{C}$ until dry weight measurement, with 2 exceptions: at night on 22 March and during the day on 23 March, they were rinsed with distilled water and preserved in $5 \%$ Bouin's solution.

Natural food assemblages enriched with Strombidium conicum. Natural seawater containing cultured $S$. conicum was given as food from the night of 20 March to the day of 22 March at ERCMB (Table 1). $S$. conicum was added to obtain various biomasses of naked ciliates. Natural surface seawater was collected in a plastic bucket from the innermost part of Onagawa Bay and was filtered through a $200 \mu \mathrm{m}$ mesh. Incubation water was prepared by mixing 201 of filtered natural seawater with $250 \mathrm{ml}$ of $S$. conicum culture, to give a final $S$. conicum density of 2500 cells $\mathbf{l}^{-1}$. However, no enrichment effect was apparent, and the $S$. conicum in the culture bottles may have been dead. Incubation water was left for 1.8 to $3.0 \mathrm{~h}$, and then for a further $1 \mathrm{~h}$ after addition of the $S$. conicum cultures in order to acclimatize the food assemblage. Experiments were done in two 201 bottles - 1 with 5 live euphausiids, 1 without euphausiids as a control - which were incubated for $6 \mathrm{~h}$ at 9.4 to $10.9^{\circ} \mathrm{C}$ in the dark. The preparation of water samples for chlorophyll a analysis and ciliate enumeration was the same as the above experiments using natural food assemblages. Incubated Euphausia pacifica was rinsed with distilled water to remove attached materials, and preserved in $5 \%$ Bouin's solution.

Analysis of samples. A 50 to $100 \mathrm{ml}$ subsample, depending on ciliate abundance, was collected from the Lugol-preserved water samples in replicate at the start and end of each experiment (a single subsample was collected in the experiments in September and October 2000) and allowed to settle for $24 \mathrm{~h}$. The numbers of the different groups of microplankton were then counted using a modification of the Utermöhl method (Taniguchi 1977) under $100 \times$ or $200 \times$ magnification. The dimensions of the cells of naked ciliates and live tintinnids were measured, and their carbon content was estimated from cell volume with a conversion factor of $0.19{\mathrm{pg} \mathrm{m}^{-3}}^{-}$(Putt \& Stoecker 1989).

Chlorophyll $a$ on the filters was extracted in $10 \mathrm{ml}$ $90 \%$ acetone for $24 \mathrm{~h}$ at $-25^{\circ} \mathrm{C}$, and fluorescence was determined before and after acidification on a Turner Designs fluorometer (Holm-Hansen et al. 1965). Phytoplankton carbon was estimated assuming a carbon: chlorophyll a ratio of 30 (Strickland 1960, Geider 1987).

Total length, from the anterior tip of the rostrum to the distal end of the telson, of Euphausia pacifica was measured immediately after the experiment. Individual dry mass was obtained by drying at $60^{\circ} \mathrm{C}$ for $24 \mathrm{~h}$ in a drying oven (Lovegrove 1962), desiccation for $24 \mathrm{~h}$ 
while cooling to room temperature, and weighing on a Mettler microbalance with a reading accuracy of $0.01 \mathrm{mg}$. Except for March, the carbon weight of E. pacifica was calculated from the dry mass by assuming that the carbon weight of an adult is $43 \%$ of its dry mass (Iguchi \& Ikeda 1998). For the experiments in which Strombidium conicum was used as the sole prey, the carbon weight of E. pacifica was estimated from its total length using the equation of Ross (1982). The ingestion rates of $E$. pacifica on ciliates and chlorophyll a were calculated with a modification of Frost's (1972) equation (Båmstedt et al. 2000).

\section{RESULTS AND DISCUSSION}

Euphausia pacifica did not consume copepods of any developmental stages, although nauplii were present at $<60$ individuals $\mathrm{l}^{-1}$ in the experimental bottles. Chlorophyll $a$ and the number of ciliates (tintinnids and naked ciliates) and copepods in the control bottles did not change significantly during the experiments ( $t$-test, $\mathrm{p}>0.15$ ). Therefore, the effect of feeding of copepods on phytoplankton or ciliates seemed small.
When cultured Strombidium conicum was given as the sole prey at high concentration (HSC), ingestion rates of Euphausia pacifica were $3.24 \mu \mathrm{g} \mathrm{C} \mathrm{krill}{ }^{-1} \mathrm{~h}^{-1}$ at night, and $1.01 \mu \mathrm{gC} \mathrm{krill}^{-1} \mathrm{~h}^{-1}$ during the day (Table 2). The ingestion rates at low $S$. conicum concentration (LSC) were lower, being $0.04 \mu \mathrm{g} \mathrm{C} \mathrm{krill}{ }^{-1} \mathrm{~h}^{-1}$ at night and $0.07 \mu \mathrm{gC} \mathrm{krill}^{-1} \mathrm{~h}^{-1}$ during the day (Table 2). In the experiments in which natural seawater with or without cultured $S$. conicum was given, ingestion rates of $E$. pacifica on naked ciliates ranged from 0.03 to $1.98 \mu \mathrm{g} \mathrm{C} \mathrm{krill}{ }^{-1} \mathrm{~h}^{-1}$ (Table 2). Our results suggest that $E$. pacifica ingests naked ciliates.

Based on incubation experiments, Atkinson \& Snÿder (1997) reported that protozoans were a significant food item for Euphausia superba. In the present study, the daily ration at HSC ranged from 0.94 to $2.28 \%$ of body carbon, while that at LSC ranged from 0.05 to $0.06 \%$ of body carbon (Table 2). When natural seawater with or without cultured Strombidium conicum was given, the daily ration on naked ciliates ranged from 0.02 to $1.76 \%$ of body carbon (Table 2). In an experimental study at 8 and $12^{\circ} \mathrm{C}, 2$ to $4 \%$ of body carbon was needed per day for E. pacifica to maintain their growth, respiration, and reproduction (Ross 1982). Our incubation temperature ranged from

Table 2. Euphausia pacifica. Ingestion $\left(\mu \mathrm{gC} \mathrm{krill}^{-1} \mathrm{~h}^{-1}\right)$ and clearance rates $\left(\mathrm{krill}^{-1} \mathrm{~h}^{-1}\right)$, and daily ration (\% body C) of naked ciliates, tintinnids and phytoplankton in each experiment. Surface seawater filtered through $200 \mu \mathrm{m}$ mesh. N: night; D: day; HSC: high Strombidium conicum concentration (5000 cells $\left.{ }^{-1}\right)$; LSC: low S. conicum concentration $\left(300\right.$ cells $\left.1^{-1}\right)$; -: not determined

\begin{tabular}{|c|c|c|c|c|c|c|c|c|c|c|c|}
\hline \multirow[t]{3}{*}{ Food source } & \multicolumn{3}{|c|}{ Naked ciliates } & \multicolumn{3}{|c|}{ - Tintinnids - } & \multicolumn{5}{|c|}{ Phytoplankton } \\
\hline & \multirow[t]{2}{*}{$\begin{array}{l}\text { Ingestion } \\
\text { rate }\end{array}$} & \multirow[t]{2}{*}{$\begin{array}{l}\text { Clearance } \\
\text { rate }\end{array}$} & \multirow[t]{2}{*}{$\begin{array}{l}\text { Daily } \\
\text { ration }\end{array}$} & \multirow[t]{2}{*}{$\begin{array}{l}\text { Ingestion } \\
\text { rate }\end{array}$} & \multirow[t]{2}{*}{$\begin{array}{l}\text { Clearance } \\
\text { rate }\end{array}$} & \multirow[t]{2}{*}{$\begin{array}{l}\text { Daily } \\
\text { ration }\end{array}$} & \multicolumn{2}{|c|}{$\begin{array}{l}\text { Ingestion } \\
\text { rate }\end{array}$} & \multicolumn{2}{|c|}{$\begin{array}{l}\text { Clearance } \\
\text { rate }\end{array}$} & \multirow{2}{*}{$\begin{array}{l}\text { Daily } \\
\text { ration }\end{array}$} \\
\hline & & & & & & & $<10 \mu \mathrm{m}$ & $>10 \mu \mathrm{m}$ & $<10 \mu \mathrm{m}$ & $>10 \mu \mathrm{m}$ & \\
\hline \multicolumn{12}{|c|}{ Strombidium conicum } \\
\hline 22 Mar 01 (N) HSC & C 3.24 & 0.21 & 2.28 & & & & & & & & \\
\hline 22 Mar 01 (N) LSC & C $\quad 0.04$ & 0.03 & 0.05 & & & & & & & & \\
\hline 23 Mar 01 (D) HSC & C 1.01 & 0.03 & 0.94 & & & & & & & & \\
\hline 23 Mar 01 (D) LSC & C $\quad 0.07$ & 0.05 & 0.06 & & & & & & & & \\
\hline \multicolumn{12}{|l|}{ Natural seawater } \\
\hline 14 Sep 00 (N) & 0.06 & 0.14 & 0.09 & - & - & - & - & - & - & - & - \\
\hline 3 Oct 00 (D) & - & - & - & - & - & - & - & - & - & - & - \\
\hline 5 Oct $00 \quad(\mathrm{~N})$ & - & - & - & - & - & - & - & $0.40^{\mathrm{b}}$ & - & $0.01^{\mathrm{b}}$ & 0.33 \\
\hline 6 Oct $00 \quad(\mathrm{~N})$ & - & - & - & - & - & - & - & $0.14^{\mathrm{b}}$ & - & $0.03^{\mathrm{b}}$ & 0.11 \\
\hline 7 Oct $00 \quad(\mathrm{~N})$ & 0.80 & 0.84 & 0.61 & - & - & - & - & - & - & - & - \\
\hline $22 \operatorname{Mar} 01$ (N) & 1.30 & 0.09 & 1.22 & - & - & - & - & - & - & - & - \\
\hline 23 Mar 01 (D) & - & - & - & 0.13 & 1.46 & 0.13 & 10.45 & - & 0.25 & - & 10.24 \\
\hline 11 Apr $01(\mathrm{~N})$ & 1.95 & 0.29 & 1.12 & 0.47 & 0.32 & 0.27 & - & 34.25 & - & 0.27 & 19.73 \\
\hline 14 Apr 01 (N) & 0.34 & 0.14 & 0.23 & - & - & - & - & - & - & - & - \\
\hline $14 \mathrm{Apr} 01^{\mathrm{a}}(\mathrm{N})$ & - & - & - & - & - & - & 0.56 & - & 0.14 & - & 0.35 \\
\hline $15 \mathrm{Apr} 01^{\mathrm{a}}(\mathrm{N})$ & - & - & - & - & - & - & 0.07 & - & 0.11 & - & 0.04 \\
\hline \multicolumn{12}{|c|}{ Natural seawter $+S$. conicum } \\
\hline 20 Mar 01 (N) & - & - & - & 0.04 & 0.13 & 0.03 & - & - & - & - & - \\
\hline 21 Mar 01 (D) & 0.03 & 0.01 & 0.02 & 0.09 & 0.92 & 0.07 & - & 0.69 & - & 0.24 & 0.56 \\
\hline 21 Mar $01(\mathrm{~N})$ & 1.98 & 0.12 & 1.76 & 0.16 & 0.49 & 0.14 & - & 4.41 & - & 0.37 & 3.94 \\
\hline 22 Mar 01 (D) & 1.53 & 0.33 & 1.26 & - & - & - & - & 0.84 & - & 0.03 & 0.70 \\
\hline
\end{tabular}


8.7 to $12.9^{\circ} \mathrm{C}$ except on 3 October, and was similar to that in the study of Ross (1982). In stomach-content analyses, daily rations calculated by converting prey volumes to carbon weight were less than $3.6 \%$ of the body carbon throughout the year (Nakagawa et al. 2001, Taki et al. 2002). In the present study, however, diatoms were present in the incubation water in the experiments in which $S$. conicum was given as the sole prey. Ingestion rates of E. pacifica on diatoms by number ranged from 0 to 2.8 cells krill $^{-1} \mathrm{~h}^{-1}$ at LSC, and from 0 to 95.9 cells $\mathrm{krill}^{-1} \mathrm{~h}^{-1}$ at HSC. Ingestion rates on naked ciliates were higher, ranging from 0 to 14.1 cells $\mathrm{krill}^{-1} \mathrm{~h}^{-1}$ at LSC and from 7.6 to 216.6 cells $\mathrm{krill}^{-1} \mathrm{~h}^{-1}$ at HSC, than those on diatoms. Moreover, Isochrysis sp. was not eliminated from $S$. conicum cultures in order not to hurt $S$. conicum in washing it, although E. pacifica could not consume Isochrysis sp. effectively because of its small size (Parsons et al. 1967). Therefore, when diatoms and Isochrysis sp. are not present in the incubation water, ingestion rates and daily rations of E. pacifica on $S$. conicum might be higher than the values we obtained. These results suggest that naked ciliates alone could fulfill much of the energy requirements of E. pacifica.

In several laboratory and field experiments, copepods ingested protozoans, mainly ciliates, at higher rates than they ingested phytoplankton (Wiadnyana \& Rassoulzadegan 1989, Gifford \& Dagg 1991, Fessenden \& Cowles 1994). In the present study, although the initial biomass was dominated by phytoplankton in all the experiments, ranging from 63.3 to $98.6 \%$, and the initial biomass of ciliates (tintinnids and naked ciliates) was less than $36.0 \%$, ciliates dominated in the diet in some instances: on 14 September and 7 October 2000, and on 22 March and 14 April 2001, when natural food assemblages were given, and 20 and 22 March when natural seawater enriched with Strombidium conicum was given (Fig. 1). Euphausia pacifica ingested tintinnids at higher clearance rates $(0.13$ to $\left.1.46 \mathrm{l} \mathrm{krill}^{-1} \mathrm{~h}^{-1}\right)$ than phytoplankton (0.01 to $0.37 \mathrm{l}$ $\mathrm{krill}^{-1} \mathrm{~h}^{-1}$ ) (Table 2). The clearance rates on naked ciliates ranged from 0.01 to $0.84 \mathrm{l} \mathrm{krill}^{-1} \mathrm{~h}^{-1}$, which lies between the values for tintinnids and phytoplankton (Table 2). E. pacifica ingested ciliates (tintinnids and naked ciliates) at higher clearance rates than phytoplankton. Moreover, Broglio et al. (2001) reported that the copepod Acartia clausi ingested the tintinnid Metacylis sp. at a higher rate than S. spiralis, S. spiralis escaping the attacking $A$. clausi with rapid jumps. Metacylis sp. lacked any effective behavioral response to the predator, showing a swimming pattern typical of many tintinnids, with steep helical trajectories without jumps. Therefore, it may be easier for E. pacifica to capture tintinnids than to capture naked ciliates. However, naked ciliates may be more important as prey of

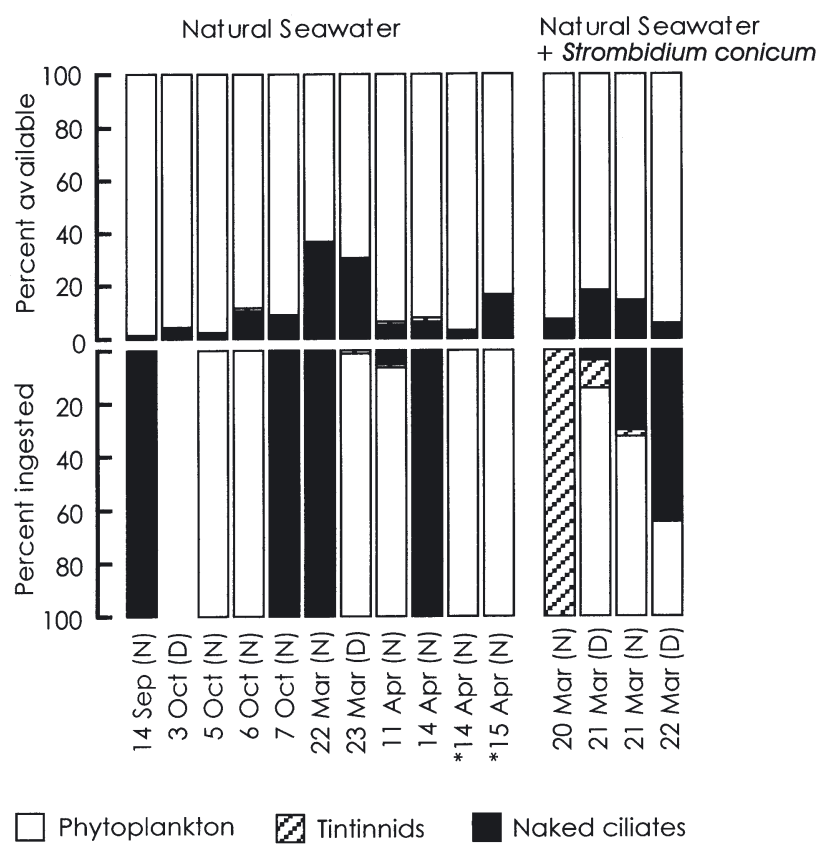

Fig. 1. Euphausia pacifica. Initial contribution (carbon biomass) of each prey item to total prey biomass (Percent available) and contribution to total stomach content-carbon (Percent ingested) in each experiment from September 2000 to April 2001. N: night; D: day; surface seawater filtered through $200 \mu \mathrm{m}$ mesh; ${ }^{*}$ through $40 \mu \mathrm{m}$ mesh

E. pacifica because they are more numerous than tintinnids.

Based on stomach fullness, feeding activity of Euphausia pacifica at night is reported to be higher than during the day (Ponomareva 1963, Endo 1981, Nakagawa et al. 2003). When Strombidium conicum was given as the sole prey at HSC, feeding rates on S. conicum at night were higher than that during the day. When natural food assemblages were given, however, there was an instance (22 March) when feeding rates on naked ciliates during the day were higher than those at night. Moreover, ingestion rates and initial concentrations did not show a significant correlation ( $t$-test, p > 0.2) even when excluding the daytime experiments ( $t$-test, $\mathrm{p}>0.06$ ). For a better understanding of the feeding behavior of E. pacifica on ciliates, more work is needed, taking into account the availability and size composition of other food items.

Naked ciliates have been recognized as ubiquitous and important components of marine microbial food webs (Beers 1986). Euphausia pacifica does not ingest smaller components of microbial food webs such as bacteria either directly and efficiently. However, the present study indirectly demonstrates that E. pacifica ingests naked ciliates and plays a role in linking microbial food webs to the classical grazing food chains. 
Acknowledgements. We thank Dr. A. Taniguchi for his helpful comments on this work. This manuscript was improved by the constructive comments of anonymous referees. The officers and crew of the RV 'Tansei-Maru' and RV 'WakatakaMaru', and captain K. Abe of the FV 'Juho-Maru' are gratefully acknowledged for their assistance with the collection of samples.

\section{LITERATURE CITED}

Atkinson A, Snÿder R (1997) Krill-copepod interactions at South Georgia, Antarctica. I. Omnivory by Euphausia superba. Mar Ecol Prog Ser 160:63-76

Båmstedt U, Gifford DJ, Irigoien X, Atkinson A, Roman M (2000) Feeding. In: Harris R, Wiebe P, Lenz J, Skjoldal HR, Huntley M (eds) ICES zooplankton methodology manual. Academic Press, London, p 297-399

Beers JR (1986) Organisms and the food web. In: Eppley RW (ed) Plankton dynamics of the Southern California Bight. Springer-Verlag, Berlin, p 84-175

Broglio E, Johansson M, Jonsson PR (2001) Trophic interaction between copepods and ciliates: effects of prey swimming behavior on predation risk. Mar Ecol Prog Ser 220: 179-186

Endo Y (1981) Ecological studies on the euphausiids occurring in the Sanriku waters with special reference to their life history and aggregated distribution. $\mathrm{PhD}$ thesis, Tohoku University, Sendai (in Japanese with English abstract)

Fessenden L, Cowles TJ (1994) Copepod predation on phagotrophic ciliates in Oregon coastal waters. Mar Ecol Prog Ser 107:103-111

Frost BW (1972) Effects of size and concentration of food particles on the feeding behavior of the marine planktonic copepod Calanus pacificus. Limnol Oceanogr 6:805-815

Geider RJ (1987) Light and temperature dependence of the carbon to chlorophyll a ratio in microalgae and cyanobacteria: implications for physiology and growth of phytoplankton. New Phytol 106:1-34

Gifford DJ (1993) Consumption of protozoa by copepods feeding on natural microplankton assemblages. In: Kemp PF, Sherr BF, Sherr EB, Cole JJ (eds) Handbook of methods in aquatic microbial ecology. Lewis Publishers, Boca Raton, FL, p 723-729

Gifford DJ, Dagg MJ (1991) The microzooplankton-mesozooplankton link: consumption of planktonic protozoa by the calanoid copepods Acartia tonsa Dana and Neocalanus plumchrus Murukawa. Mar Microb Food Webs 5:161-177

Holm-Hansen O, Lorenzen CJ, Holmes RW, Strickland JDH (1965) Fluorometric determination of chlorophyll. J Cons Perm Int Explor Mer 30:3-15

Iguchi N, Ikeda T (1998) Elemental composition $(\mathrm{C}, \mathrm{H}, \mathrm{N})$ of the euphausiid Euphausia pacifica in Toyama Bay, southern Japan Sea. Plankton Biol Ecol 45:79-84

Ito $H$ (2002) Standing crops and productivities of planktonic ciliates in the subarctic and subtropical North Pacific. PhD

Editorial responsibility: Otto Kinne (Editor),

Oldendorf/Luhe, Germany thesis, Tohoku University, Sendai (in Japanese with English abstract)

Ito H, Taniguchi A (2001) Standing crops of planktonic ciliates and copepod nauplii in the subarctic North Pacific and the Bering Sea in summer. J Oceanogr 57:333-339

Kawaguchi S, Toda T (1997) Discovery of ciliates reproducing in the gut of Antarctic krill. Polar Biol 18:158-160

Lovegrove T (1962) The effect of various factors on dry weight values. Rapp P-V Réun Cons Int Explor Mer 153:86-91

Mauchline J, Fisher LR (1969) The biology of euphausiids. Adv Mar Biol 7:1-454

Nakagawa Y, Endo Y, Taki K (2001) Diet of Euphausia pacifica Hansen in Sanriku waters off northeastern Japan. Plankton Biol Ecol 48:68-77

Nakagawa Y, Endo Y, Taki K (2002) Contributions of heterotrophic and autotrophic prey to the diet of euphausiid, Euphausia pacifica in the coastal waters off northeastern Japan. Polar Biosci 15:52-65

Nakagawa Y, Endo Y, Sugisaki H (2003) Feeding rhythm and vertical migration of the euphausiid Euphausia pacifica in coastal waters of north-eastern Japan during fall. J Plankton Res 25:633-644

Parsons, TR, LeBrasseur RJ, Fulton JD (1967) Some observations on the dependence of zooplankton grazing on the cell size and concentration of phytoplankton blooms. J Oceanogr Soc Jpn 23:10-17

Perissinotto R, Pakhomov EA, McQuaid CD, Froneman P (1997) In situ grazing rates and daily ration of Antarctic krill Euphausia superba feeding on phytoplankton at the Antarctic Polar Front and the Marginal Ice Zone. Mar Ecol Prog Ser 160:77-91

Pierce RW, Turner JT (1992) Ecology of planktonic ciliates in marine food webs. Rev Aquat Sci 6:139-181

Ponomareva LA (1963) Euphausiids of the North Pacific, their distribution and ecology. Dokl Akad Nauk SSSR, Moscow (English translation, Israel Program for Scientific Translations, Jerusalem, 1966)

Putt M, Stoecker DK (1989) An experimentally determined carbon:volume ratio for marine 'oligotrichous' ciliates from estuarine and coastal waters. Limnol Oceanogr 34:1097-1103

Ross RM (1982) Energetics of Euphausia pacifica. I. Effects of body carbon and nitrogen and temperature on measured and predicted production. Mar Biol 68:1-13

Stoecker DK, Capuzzo JM (1990) Predation of protozoa: its importance to zooplankton. J Plankton Res 12:891-908

Strickland JDH (1960) Measuring the production of marine phytoplankton. Bull Fish Res Board Can 122:1-172

Taki K, Tsubo J, Nakagawa Y, Endo Y (2002) Diet of Euphausia pacifica Hansen in southeastern Hokkaido and Joban waters off northeastern Japan. Bull Jpn Soc Fish Oceanogr 66:155-163 (in Japanese with English abstract)

Taniguchi A (1977) Distribution of microzooplankton in the Philippine Sea and the Celebes Sea in summer, 1972. J Oceanogr Soc Jpn 33:82-89

Wiadnyana NN, Rassoulzadegan F (1989) Selective feeding of Acartia clausi and Centropages typicus on microzooplankton. Mar Ecol Prog Ser 53:37-45

Submitted: July 14, 2003; Accepted: February 3, 2004

Proofs received from author(s): April 14, 2004 